Hasenfus, N. \& Magaro, P. (1976) Creativity and schizophrenia: An equality of empirical constructs. British Journal of Psychiatry, 129, 346-9.

Heston, L. L. (1966) Psychiatric disorders in foster home reared children of schizophrenic mothers. British Journal of Psychiatry, 112, 819-25.

HuXley, J., Mayr, E., Osmond, H. \& Hoffer, A. (1964) Schizophrenia as a genetic morphism. Nature, 204, 220-1.

JARVIK, L. F. \& CHADWICK, S. B. (1973) Schizophrenia and survival. In Psychopathology: Contributions from the Social, Behavioral, and Biological Sciences (eds. M. Hammer, K. Salzinger and S. Sutton). New York: Wiley, pp. 57-73.

KARLSSON, J. L. (1968) Genealogic studies of schizophrenia. In The Transmission of Schizophrenia (eds. D. Rosenthal and S. S. Kety). Oxford: Pergamon Press, pp 85-94.

Kuttiner, R. E., Lorincz, A. B. \& Swan, D. A. (1967) The schizophrenia gene and social evolution. Psychological Reports, 20, 407-12.

LewIs, N. D. C. (1966) History of the nosology and the evolution of the concepts of schizophrenia. In Psychopathology of Schizophrenia (eds. P. H. Hoch and J. Zubin). New York: Grune and Stratton, pp 1-18.

Sengel, R. A. \& Lovallo, W. R. (1980) A random process model of cognitive deficit in schizophrenia. Schizophrenia Bulletin, 6, 526-35.

\section{BIOFEEDBACK AND RELAXATION IN} ANXIETY

DeAR SiR,

Drs Leboeuf and Lodge reported in the September issue of the Journal that frontalis EMG biofeedback and progressive relaxation while equally effective in reducing levels of anxiety were clinically unimpressive as antianxiety measures (Journal, 1980, 137, 279-84). They also noted that reduction in muscle tension did not correlate with the associated anxiety relief.

A mental device to dwell upon, a passive attitude, comfortable position and a quiet atmosphere have been listed as the main ingredients of all relaxation therapies (Benson, 1974). The only difference between EMG biofeedback and progressive relaxation would seem to be in the mental device used to minimize distraction. The feedback signal of the biofeedback machine and the subjective feeling of muscle tension in progressive relaxation are more likely to serve as devices to dwell upon rather than as specific aids to lower anxiety. Several other investigators have also reported absent correlations between reductions in muscle tension and anxiety (Surwit and Keefe, 1978; Raskin et al, 1980). Furthermore, the concept that relaxation of the frontal muscle will readily generalize to the rest of the body is not supported by scientific evidence (Surwit and Keefe, 1978). In a similar research project carried out in our laboratory, in addition to the findings reported by Leboeuf and
Lodge, we found a significant correlation between Stanford Hypnotic Susceptibility Score and Anxiety Reduction $(\mathrm{r}=.44, \mathrm{P}<.05)$. Highly hypnotisable individuals are thought to excel in their ability to concentrate (Karlin, 1979). This adds further support to the notion that the feedback signal of the biofeedback machine serves as an emotionally neutral signal for the patient to focus on while relaxing.

It is unclear at the moment, how relaxation therapies compare with the alternative pharmacological treatments. It should be noted that the relaxation therapies are free of problems of drug toxicity and dependence. A recent study which compared biofeedback treatment to diazepam on forty anxious subjects found both forms of treatments to be equally effective at the end of treatment and biofeedback to be more effective at the three month and six month follow-up evaluations (Lavallee et al, 1977). More information is needed before any furm conclusions can be drawn in this regard.

Rơ J. Mathew

Maxine L. Weinman

PATRICIA ROUPERT

Psychosomatic Research Section,

Texas Research Institute of Mental Sciences,

Houston, Texas 77030

\section{References}

Benson, H., Beary, J. F. \& Carọl, M. P. (1974) The relaxation response. Psychiatry, 37, 37-46.

KARLIN, R. A. (1979) Hypnotisability and attention. Journal of Abnormal Psychology, 88, 92-5.

Lavallee, Y. J., Lamontagne, Y., Pinard, G. et al (1977) Effects of EMG biofeedback, diazepam and their combination on chronic anxiety. Journal of Psychosamatic Research, 21, 65-71.

Raskin, M., Bals, L. R. \& Peeke, H. V. (1980) Muscle biofeedback and transcendental meditation. Archlves of General Psychiatry, 37, 93-7.

SURWT, R. S. \& KEEFE, F. J. (1978) Frontalis EMG feedback training: An electronic panacea? Behavior Therapy, 9, 7797-2.

\section{AN EARLY CASE OF BATTLE HYSTERIA}

DeAR SIR,

With reference to Dr M. A. Patton's letter, (Journal, February 1981, 138, 182-83), about an 'Early Case of Battle Hysteria', I would like to mention that a typical case of combat hysteria, perhaps the earliest, is masterfully described by Herodotus whom I quote below:

". . In this fight of Marathon there were slain of the foreigners about six thousand four hundred men, and of the Athenians a hundred ninety-two. These are the numbers of them that fell on both sides. And it fell out that a marvellous thing happened: a 